radical body concepts, such as the blended wing-body that was pioneered in the US Air Forces' B2 stealth bomber. In these designs the tube-like fuselage and tail are eliminated, turning the entire aircraft into a lift surface. A blended wing-body design currently being ground-tested by Boeing and NASA (pictured) promises a $20 \%$ fuel reduction. But industry watchers are unsure if passengers would accept such a design: they'd have to sit in a wide, windowless compartment, and those near the wing ends would be shaken up and down whenever the airliner banked. Airport gates would also have to be entirely redesigned to accommodate such a plane.

\section{Fuelling change}

The industry is also looking at how new fuels could help it to assuage environmental concerns. Biofuels have obvious attractions provided the public accepts that their growth and combustion are generating no net carbon emissions. Bioethanol, the most popular biofuel for car engines, will freeze at high altitudes, but biodiesel and biobutanol could each be burned in conventional turbofan engines. Richard Branson, chairman of London-based Virgin Airlines, pledged to fly a commercial jet on biofuels in 2008, and is working with Boeing and the aeroengine division of General Electric to test candidate fuels.

The ultimate zero-emissions fuel may prove to be hydrogen, which could easily be burned by conventional jet engines with no carbon emissions. First, the world will have to figure out how to make and distribute hydrogen cheaply and safely. And even given that, planes would require a redesign. Although liquid hydrogen provides three times the energy of the same weight of kerosene, it takes up seven times as much space. That would require aircraft with bigger fuel tanks, as well as the insulation to keep the liquid cool.

Once a plane exists with the cooling equipment that allows it to use liquid hydrogen as fuel, the potential exists for a more efficient allelectric plane, says Gerald Brown, a physicist at NASA Glenn Research Center in Cleveland, Ohio. Conventional generators are too heavy to be efficient on aircraft. But with a source of cold hydrogen, a superconducting generator and electric motors start to make sense, he argues, and might be more efficient than today's turbofans (P. J. Masson et al. Supercond. Sci. Technol. 20, 748-756; 2007).

In the end, the aviation industry will seek to combine all of these approaches in a concerted bid to head off accusations that its rapid growth is spurring global warming. "We have a lot of creative people with a lot of great ideas. I'd say nothing's off the table," says Boeing's Glover.

\section{IN BRIEF}

BRAZIL DEAL Abbott Laboratories, the Illinois-based drug company, reached agreement with the Brazilian government to sell its AIDS drug Kaletra there for a reduced price - lifting the threat that Brazil might license it compulsorily. On 4 July, the company said it would sell it there for $\$ 1,000$ per patient per year, down by about $30 \%$. Abbott has drawn criticism from AIDS activists for its approach to marketing Kaletra in Thailand, where it has withdrawn an application to sell a heat-stable version of the drug (see Nature 448, 14; 2007).

ALL IN HAND A 2,000-page guidebook has been compiled to help specialists in public health and agriculture to navigate their way through the thickets of intellectual property. The IPHandbook (www.iphandbook.org) has been produced by two non-profit organizations that specialize in opening up access to intellectual property in health and agriculture, respectively, as a resource for scientists and government officials, especially in poor countries. Support from the Rockefeller Foundation and other sponsors will permit its free distribution in low-income nations.

FLOAT ABANDONED A company seeking to develop medical technologies at the University of Liverpool, UK, withdrew plans for an initial public share offering on London's Alternative Investment Market (AIM). ULive, which has been seeking to exploit intellectual property developed at the university's labs, had hoped to raise $£ 20$ million (US\$40 million) in late June, in a flotation that would have valued it at $£ 70$ million. But the number of initial public offerings on the AIM is down by half on last year, and lack of investor interest in recent offerings from small companies led ULive to withdraw its plan.

\section{MARKET WATCH}

\section{BIOTECHNOLOGY STOCKS}

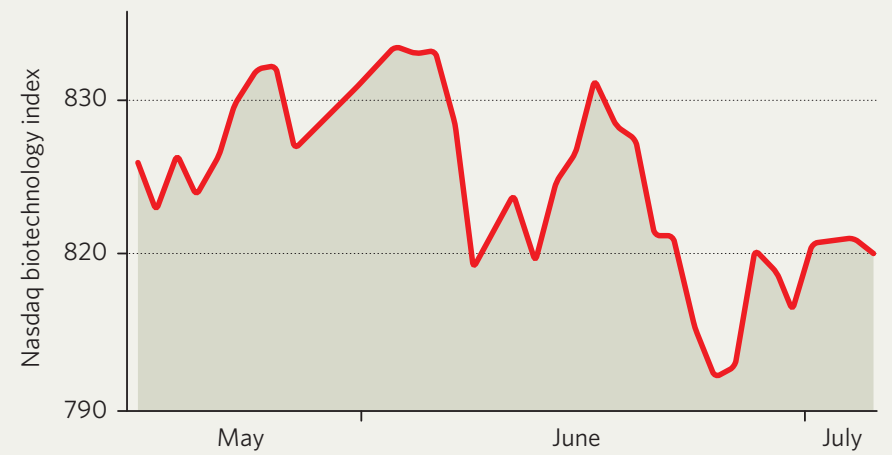

This week Wood Mackenzie, an Edinburghbased research and consulting firm, reviews recent trends in biotechnology stocks.

The Nasdaq biotechnology index experienced a choppy ride - overlying a general, downward trend - during May and June. The index lost more than 4\% of its value, although it is still up nearly $2 \%$ on the start of 2007 . By contrast, broader market indices made modest gains during the same period.

As it is weighted according to market capitalization, the biotechnology index is closely tied to the fortunes of its largest component company, Amgen. The Californian company has suffered from concerns in the United States over the safety of erythropoiesis-stimulating agents in cancer treatment, of which Amgen has two: Epogen and Aranesp. Investors reacted badly to the threat to Amgen's largest franchise, which accounts for about half of the company's sales. The company's share price fell, and was down nearly $12 \%$ over the period (see Nature 447, 899; 2007).

Other companies in the cancer market have had misfortunes, too. In early May, the US Food and Drug Administration (FDA) said it would require more data before approving a therapeutic prostate cancer vaccine, Provenge, under development by Seattle-based Dendreon. Its shares fell more than $60 \%$ on the news, wiping out gains made in March. And in early June, the FDA temporarily halted all clinical trials for the ovarian cancer drug candidate Telcyta, on safety grounds. Shares of its developer, Telik of Palo Alto, California, lost almost half their value on the news.

Summer is customarily a slow time for stock markets in general, and biotechnology shares in particular. This year, Amgen's misfortunes are unsettling investors, with many of the smaller companies in the biotech sector involuntarily joining in the slide. 